\title{
SOCIAL ACTIVITY AND HUMAN RESOURCES AS SOCIAL DEVELOPMENT FACTORS
}

\author{
Venelin Terziev \\ Academician of the Russian Academy of Natural History, Moscow, Russia, Prof. D.Sc. (Ec.), D.Sc. \\ (National Security), D.Sc. (Social Activities), Ph.D., National Military University, Veliko Tarnovo, \\ Bulgaria; University of Rousse, Rousse, Bulgaria, terziev@skmat.com
}

\begin{abstract}
Key factor for socio-economic development are people. They are the foundation of social management as a separate managerial area, the goal of which is the management of the interaction between the subject and the object, (having their social character), occurring in a particular social environment. To what degree the actions of the subject and the object, as elements of social management are adequate to the changes in the environment, is determined by their activity. Moreover, the rationalization of social managerial decisions is directly dependent on the social policy carried out.
\end{abstract}

Keywords: social development, social management, human resources.

\section{INTRODUCTION}

Key factor for socio-economic development are people. They are the foundation of social management as a separate managerial area, the goal of which is the management of the interaction between the subject and the object, (having their social character), occurring in a particular social environment. To what degree the actions of the subject and the object, as elements of social management are adequate to the changes in the environment, is determined by their activity. Moreover, the rationalization of social managerial decisions is directly dependent on the social policy carried out.

The social policy as a set of principles, legal norms, institutions and activities, aimed at creating conditions ensuring the quality of life of the citizens of a country, is an expression of the social relations between the state and its citizens. The social policy determines the safety (social, health, economic) and security of the people in the socium. This is why it is defined as "philosophy, ideology, program for influence on the demographic situation, employment of the population, level, way and quality of living of the population, „its income level and structure of consumption of material and cultural wealth,... forms of social security, social services to the population, ... providing targeted state aid to the most unprotected, the most vulnerable and poor layers of the population,... measures aimed at creating conditions for self-defense in order to maintain and improve the level of well-being...".

It is noteworthy that within the scope of social policy is included a wide arsenal of concepts (social protection, social safety, social support, social self-protection, quality of life), defined in the quoted edition. 8 From here, in the content of social policy are differentiated concrete actions of the state bodies, non-state institutions, public associations, related to the implementation of tactical and strategic objectives for the harmonization of public relations. Since the foundation of these relations is the people with their actions and skills, they are a crucial factor of social policy. Inside it are synthesized and multiplied the other components of a country's 
resources and thus they are transformed into a finished product in the planning of the goals for achieving socio-economic development, making it possible to carry out an effective social policy.

Moreover, researches show that „70\% of the world's wealth is in the form of human capital - the skills and knowledge of the people and not in physical or financial capital. The strategy of many companies today is clearly guided by the idea of human resources, stressing on individualization, service and innovation".

Put another way, human resources are the people in an organization who, by their professional and personal qualities make it possible to achieve its strategic objectives. Together with rest of the resources, they should meet the needs of the organization, and the way they are transformed into abilities, predetermines the efficiency of their use. This means that they, human resources, together with others, become function, subsystem and object of management. Reason for this is the circumstance that in terms of goal setting, they are a function of management. The application of the accumulated scientific knowledge on the general theory of systems, basing on a system approach, interacting with other management subsystems, characterizes them as a management subsystem. They are subject to management because through the forward and backward informational feedback, they are subject to management, influence for the purpose of obtaining certain result.

From here, human resource management (HRM) is defined as „a system of principles, methods, tools, legal norms, rules, criteria, requirements, standards, procedures, policies, plans and programs of formation and use of human resources in the organization, in accordance with its immediate interests and strategic objectives".

In other words, HRM is an activity resulting from the strategic objectives of the organization, which requires the implementation of a strategic management approach in taking managerial decisions, related to this resource. In this sense, the human resource is a reflection of specific social relations in the interests of social governance, as part of a nationwide management. And in an environment of dynamic changes, requiring the participation of human resources in the socio- economic processes, by maintaining and developing adequate to the changes in the social environment abilities to harmonize social relations, demands establishment of an effective system of social activity, which is also our goal of study in this publication.

\section{SOCIAL ACTIVITY AS A FACTOR OF CHANGE IN PUBLIC RELATIONS}

The social activity is inherently associated with foresight and proactive action. Put another way, it is directly related to the change in social relations caused by people, by the individual. From here, ,...social activity is the realization of a particular new norm-measure of the activity, which norm measure stands out as new in direct comparison with the established one, with that which is considered "normal" by common sense in life. The individual realizes this new norm-measure either in his own activities or in the activities of other people, their associations, public institutions... activity that generates activity".

What is noteworthy is that the essential characteristics of social activity are the change, the activities, the social subject, the public system, the public relations.

In all his actions, ,the individual intentionally makes changes in the activity and its results (his or someone else's activity) and thus causes social change and creates conditions for change (progressive or regressive)".

Social activity is objectively and subjectively conceptualized by the individual as his activity for the development of society from the position of the adopted by him specific team interests, ideals and ideas. Social activity is (1) a purposeful effort on the part of the individual (2) for a significant personal contribution to this development, (3) through the available to him forms and means (4) to the possible extent. And this determines his public predestination, the expression of which is the alignment of the social system and public relations with the dynamic changes in the social environment.

Since, in the basis of these projections and activities stays the subject, the human resource, led by the private and public interest towards change, the social activity is associated with the concept of the term interest, motivation, desire for satisfaction of needs that depend on organizational changes, the intensity of these activities is directly dependent on the factors of the social environment. All this resides within the scope of social management as part of the general managerial process and in connection with the management of human resources. In order to have efficient management of social processes, it is more than ever necessary to observe certain rules, principles which in scenes are also principles of the human resources management (HRM). This concerns the following:

- Predictability, expression of which is in synchronizing social management with the longterm strategic requirements and social needs; 
- Integration, the relevance of which is in the integration of social management in a unified framework, which to consolidate the planned strategic goals of social policy on the basis of fair treatment of the individual;

- Synchronization, expressed in planning, organizing, coordinating the activities in social management;

- Protection of information, consistent with the requirements for personal data protection, integrity and security of information, related to the individual and the social processes;

- Empathy, guaranteeing the identification of the needs of the individual and their satisfaction in a real social environment;

- Flexibility on the basis of which social management to adapt to changes in the social environment.

And all this is in the interest of the objectives and tasks of social policy, the achievement of which is a result of the activity of the human factor, understood as an individual, a team, the society, and the relations between the people in this team, in this society on the basis of self-awareness. And this activity, social in its nature, is determined by certain factors- general and specific.

\section{FACTORS OF SOCIAL ACTIVITY}

Amongst the general factors of social activity, special attention deserve:

- The common culture, which is important for the behavior of the human factor in the team, in the society;

- The special-functional culture resulting from the behavior of the individual in the realization of professional relationships;

- The motivating factors relating to the stimulation and consideration of interests of individuals in the team and in the society.

- The specific factors of social activity include:

- The way of taking management decisions, while leading are these two moments- one, when it is necessary to ensure the participation of the team, the society in the execution of the decision, and the second, when it is important to act immediately and in a short time to achieve the intended purpose;

- The way of managerial communication, while extremely important is the managerial responsibility, manifested by the so called „Ruling Five”, illustrated by the fingers of the hand.

Through this approach the following questions receive their answers: greater pressure (the thumb); who is to blame (the index finger); whose is the choice (the middle finger); whose are the instructions (the ring finger) and who is in control (the little finger).

The application of this approach to managerial communication is essential in the implementation of managerial decisions in the social sphere, which too often should be taken depending upon the particular situation and the implementation of which is a result of the contribution of each member of the team, of the society and their team wise interaction (Terziev, 2018a-f; Terziev, Georgiev, 2018g-h; Terziev, Banabakova, Georgiev, 2018j-l; Terziev, Banabakova, Stefanov, Georgiev, 2017a; Terziev, Georgiev, Georgiev, 2017b-j; Georgiev, 2017k).

Achieving motivation in the individual sometimes determines the practice the answer to the questions of the Ruling Five to be given „face to face”.

\section{RESULTS}

The criteria for the efficiency of the social activity are dependent on the goals and tasks related to the delivery of social services to the population and the degree of their achievement. In principle, the following shall be taken into account: the goals of the social activity can be studied on the level of society, regions, towns and villages, areas, groups of population and individuals.

First, the criteria for the efficiency of the social activity need to reflect the effectiveness of all types, forms and methods of social service of the population; second, they need to demonstrate the degree of effectiveness of the activity of the administration and the social institutions under the present day conditions in Bulgaria, where sweeping and complicated reforms are in place. Third, the criteria and indicators shall reflect the degree of efficiency of the leaders and of the management of the targeted and systematic social work with the population and the individuals who need professional social support. 
Several approaches for ascertaining the effectiveness of the implemented social programmes can be employed.

The first is related to the objective assessment of the ratio of achieved results (output) and the associated costs. In this case a key problem is the measurement (description) of the results (output) and the costs. As far as the costs can be estimated and planned, so can the effectiveness of the social service be presumed, planned and actually achieve.

Another approach focuses on the assessment of the effectiveness of the social activity in terms of the degree of satisfaction of the social needs and expectations of the serviced customers (users and beneficiaries of the project or programme). The subjective methods of assessment e.g. opinions, judgments, views (expressed about somebody or something more or less specifically) and the specific subject who performs the assessment of the effectiveness of the social activity are of great significance here. Therefore, in this case it is important to define and select the relevant source of information for the assessment (managers, specialists, representatives of surveillance bodies, users etc.); in other words, the subject is the bearer of information that is significant for the assessment. Moreover, it shall be taken into account that the assessment-related information derived from individuals is subjective. The more subjects are engaged in the assessment, the more this assessment will seek to gain (under other equivalent conditions) an objective and reliable picture of the activity of the social services and the implementation of the specific social programme/project on employment.

The complicated nature of the assessment requires a targeted organization of the process of obtaining opinions, judgments and conclusions, expressed through specific forms and methods. In this case, this concerns the procedural and organizational aspect of the term „assessment of the effectiveness of the social service". If we want to assess someone or something, we need to organize the process of assessment (collecting and processing the assessment information), devising and employing specific assessment procedures (including for example complex methods of assessment verification).

The whole diversity of opinions given by various subjects go through certain procedures and stages during the process of assessment and turn into the resultant (final) assessments Generally, the organizational process of assessing the final information can be used to draw practical significant conclusions, to carry out relevant events and activities and to develop programmes for enhancing the effectiveness.

Before the start of the practical measurement of the effectiveness of the social activity, the researchers inevitably have to pose a number of questions: what is the object of the assessment, what is the subjectmatter of the assessment, who is the subject of the assessment, what criteria and indicators shall be used for the assessment, etc.

Effectiveness is an aggregate, integral indicator of the qualities of the system. It is determined by the external properties of the system (the meaning of the various indicators, characterizing the capacity and the resources), as well as by the conditions where the specific system functions. Therefore, it is more precise to talk about the operational effectiveness of the system when carrying out specific tasks under certain conditions, rather than about effectiveness in general. This allows all specific indicators of quality to be functionally connected in an integral indicator, i.e. effectiveness. This type of study of the quality helps to avoid many difficulties that occur during the analysis of complex systems.

Some of the factors that help define the goals and tasks of the assessment of the effectiveness of the social services are:

The analytical capabilities of the social employment service for identification and assessment of the queries;

The resources of the social employment service for operational response to the queries;

The capacity of the social employment service (including its level of interaction with government, state, commercial and public organizations);

The social and economic conditions in the administrative area where the social employment service operates;

The qualification of the employees of the social employment service;

Special attention shall be paid to the assessment of the quality when assessing the effectiveness.

Indeed, many issues are resolved in the light of quality and the subjects of the management of the activity of the social employment service and the objects of its activity can function as indicators of quality (experts). The most typical operation during the assessment of quality is ranking. The objects (phenomena, processes) are considered ranked if a quantitative dimension of theirs corresponds to a particular quality they possess in 
varying degrees. The various social employment services use ranking in different situations. For example, ordering the objects (processes, phenomena) in terms of their position in space and time according to the degree of manifestation of a quality that cannot be measured by any objective scale, according to some measurable qualities or qualities susceptible to evaluation (as a rule the degree of manifestation of a quality used as a basis of ranking can always be practically measured), according to some quality which is generally measurable, yet at a particular moment cannot be measured due to practical or theoretical reasons.

The matrix "goal: means" can serve as a typical example when using expert assessments in the management. The cells of this matrix have to be filled in with data gained from the results of the expert assessments.

Depending on the subject-matter of the assessment there are various methodologies of assessing the effectiveness of the social protection system. We can call them provisionally "first tier methodologies” Each subject-matter of the assessment can be analyzed in more detail and respectively, there will be „second tier methodologies". There is a specific methodology of assessing the effectiveness of each type of social service (social domestic, legal, rehabilitation, psychological and consulting services, material support).

A comprehensive review and analysis of the efficiency of the government social services need to be carried out when analyzing the national social policy.

In the organization and administrative management theory the efficient management is defined as the relation between the net positive results (when the desired consequences exceed the non-desired) and the admissible costs. The decision is considered efficient if the best result has been achieved in accordance with the defined time costs and with the lowest selection costs (Terziev, Banabakova, Ilsheva, Georgiev, 2017I-m; Terziev, Kanev, 2017n; Terziev, Latyshev, Georgiev, 2017o; Terziev, 2017p; Terziev, Nichev, 2017q; Terziev, Arabska, 2017r-s; Terziev, 2017t-u).

\section{CONCLUSION}

Without claiming to be exhaustive, we believe that the application of the model of collective qualification allows the disclosure of the potential of both the individual and the team, and the society as a whole, in achieving the end results, united by the global objective of social management. This, according to the theory of leadership, is the basis of focusing "on the release of human talent and realizing the potential of the people" in managing change in the social system, in public relations, in accordance with the changes in the social environment.

Adaptation of the model of collective qualification and team work allows defining the role and place of the human factor in social management by the dependency "goal-results", which is the basis of management by result and rationalization of managerial decisions.

\section{REFERENCE LIST}

Terziev, Venelin. (2018a). The active model of a social programme and its strategic advantage. // ADVED 2018- 4th International Conference on Advances in Education and Social Sciences Abstracts \& Proceedings, 15-17 October 2018- Istanbul, Turkey, International Organization Center of Academic Research, www.ocerints.org, Istanbul, Turkey, 2018, pp. 189-203, ISBN: 978-605-82433-4-7.

Terziev, Venelin. (2018b). Active social programs development in Bulgaria: contemporary challenges and social management instruments. // ADVED 2018- 4th International Conference on Advances in Education and Social Sciences Abstracts \& Proceedings, 15-17 October 2018- Istanbul, Turkey, International Organization Center of Academic Research, www.ocerints.org, Istanbul, Turkey, 2018, pp. 149-163, ISBN: 978-605-82433-4-7.

Terziev, Venelin. (2018c). Social assistance services and integrated employment in Bulgaria. // ADVED 2018- 4th International Conference on Advances in Education and Social Sciences Abstracts \& Proceedings, 15-17 October 2018- Istanbul, Turkey, International Organization Center of Academic Research, www.ocerints.org, Istanbul, Turkey, 2018, pp. 164-177, ISBN: 978-605-82433-4-7.

Terziev, Venelin. (2018d). Impact of the labor market policies for ensuring employment. // ADVED 2018- 4th International Conference on Advances in Education and Social Sciences Abstracts \& Proceedings, 1517 October 2018- Istanbul, Turkey, International Organization Center of Academic Research, www.ocerints.org, Istanbul, Turkey, 2018, pp. 178-188, ISBN: 978-605-82433-4-7. 
Terziev, Venelin. (2018e). Importance of human resources to social development. // ADVED 2018-4th International Conference on Advances in Education and Social Sciences Abstracts \& Proceedings, 1517 October 2018- Istanbul, Turkey, International Organization Center of Academic Research, www.ocerints.org, Istanbul, Turkey, 2018, pp. 204-212, ISBN: 978-605-82433-4-7.

Terziev, Venelin. (2018f). Development of social policy as theory and practice in Bulgaria. // 3rd Central \& Eastern European LUMEN International Conference, New Approaches in Social and Humanistic Sciences NASHS 2017, Chisinau, Republic of Moldova, June 8-10, 2017, 2018, pp.493-504, ISSN (print): 2601 - 2510, ISSN (on-line): 2601 - 2529, ISSN-L: 2601 - 2510, ISBN: 978-1-910129-15-9.

Terziev, V., Georgiev, M. (2018g). Support for the development of social entrepreneurship in Bulgaria. // Knowledge - International Journal, September, 2018, Institute of Knowledge Management, Skopje, Macedonia, 26, 2018, N1, pp.57-74, ISSN 1857-923X (for e-version), ISSN 2545 - 4439 (for printed version).

Terziev, V., Georgiev, M. (2018h). A strategic framework for the development of social entrepreneurship in Bulgaria. // Knowledge - International Journal, August 2018, Institute of Knowledge Management, Skopje, Macedonia, 25, 2018, N 1, pp. 23-34, ISSN 1857-923X (for e-version), ISSN 2545 - 4439 (for printed version).

Terziev, V., Georgiev, M. (2018i). Efficient management as optimization of the organization. // Proceedings of INTCESS2018- 5th International Conference on Education and Social Sciences 5-7 February 2018Istanbul, Turkey, International Organization Center of Academic Research, www.ocerints, Istanbul, Turkey, 2018, pp. 452-461, ISBN: 978-605-82433-2-3.

Terziev, V., Banabakova, V., Georgiev, M. (2018j). Social support as part of social policy. // International journal scientific papers Vol 23.4 Promoted in Budva, Montenegro 24-27.05.2018, IKM - Skopje, 23, 2018, N 4, pp. 973-980, ISSN 1857-923X (for e-version) ISSN 2545 - 4439 (for printed version).

Terziev, V., Banabakova, V., Georgiev, M. (2018k). Structure of the social welfare system in Bulgaria. // International journal scientific papers Vol 23.4 Promoted in Budva, Montenegro 24-27.05.2018, IKM Skopje, 23, 2018, N 4, pp. 1275-1281, ISSN 1857-923X (for e-version) ISSN 2545 - 4439 (for printed version).

Terziev, V., Banabakova, V., Georgiev, M. (2018I). Modern dimensions of social policies. // International journal scientific papers Vol 23.4 Promoted in Budva, Montenegro 24-27.05.2018, IKM - Skopje, 23, 2018, N 4, pp. 935-944, ISSN 1857-923X (for e-version) ISSN 2545 - 4439 (for printed version).

Terziev, V., Banabakova, V., Stefanov, S., Georgiev, M. (2017a). The job contest - an efficient technology for selecting staff in the organization. // Fifteenth International Scientific Conference: Knowledge in practice, Bansko, Bulgaria, International Journal of Knowledge and Learning, Institute of Knowledge Management- Skopje, 20, 2017, N1, pp. 487-493, ISSN 1857-923X for e - version, ISSN 2545-4439 for printed version.

Terziev, V., Georgiev, G., Georgiev, M. (2017b). Stimulation of the staff in the organization. // World scientific extent: Collection of scientific articles, Scientific journal «Economics and finance». Agenda Publishing House, United Kingdom, 2017, pp. 32-37, ISBN 978-0-9955865-3-6.

Terziev, V., Georgiev, G., Georgiev, M. (2017c). Approaches for decision-making in the organization. // World scientific extent, Collection of scientific articles, Scientific journal «Economics and finance», Agenda Publishing House, United Kingdom, 2017, pp. 37-44, ISBN 978-0-9955865-3-6.

Terziev, V., Georgiev, G., Georgiev, M. (2017d). Possible solutions for the efficient solution of the problems in the organization. // World scientific extent, Collection of scientific articles Scientific journal «Economics and finance». Agenda Publishing House, United Kingdom, 2017, pp.44-51, ISBN 978-09955865-3-6.

Terziev, V., Georgiev, G., Georgiev, M. (2017e). Interpersonal styles for resolving conflicts in the organization. // World scientific extent, Collection of scientific articles Scientific journal «Economics and finance». Agenda Publishing House, United Kingdom, 2017, pp. 295-300, ISBN 978-0-9955865-36.

Terziev, V., Georgiev, G., Georgiev, M. (2017f). Possible solutions for management of stress and conflicts in the organization. // World scientific extent, Collection of scientific articles, Scientific journal «Economics and finance». Agenda Publishing House, United Kingdom, 2017, pp. 300-305, ISBN 9780-9955865-3-6. 
Terziev, V., Georgiev, G., Georgiev, M. (2017g). Occurrence of labor and conflict conflicts in the organization, decisions at a mobbing situation. // World scientific extent, Collection of scientific articles, Scientific journal «Economics and finance». Agenda Publishing House, United Kingdom, 2017, pp. 305-311, ISBN 978-0-9955865-3-6.

Terziev, V., Georgiev, G., Georgiev, M. (2017h). Recognizing mobbing and limitation of its activities in the organization. // World scientific extent, Collection of scientific articles, Scientific journal «Economics and finance». Agenda Publishing House, United Kingdom, 2017, pp. 311-317, ISBN 978-0-9955865-36.

Terziev, V., Georgiev, G., Georgiev, M. (2017i). Methods for resolving conflicts and managing stress at the workplace. // World scientific extent, Collection of scientific articles, Scientific journal «Economics and finance». Agenda Publishing House, United Kingdom, 2017, pp. 317-324, ISBN 978-0-9955865-3-6.

Terziev, V., Georgiev, G., Georgiev, M. (2017j). Management styles in the organization. // World scientific extent, Collection of scientific articles, Scientific journal «Economics and finance». Agenda Publishing House, United Kingdom, 2017, pp. 324-329, ISBN 978-0-9955865-3-6.

Georgiev, Marin. (2017k). The Role of the Balanced Scorecard as a tool of strategic management and control. // Journal of innovations and sustainability. Bulgaria, 3, 2017, N 2, pp. 31-63, ISSN 2367-8127 (CD-ROM), ISSN 2367-8151 (on-line).

Terziev, V., Banabakova, V., Ilsheva, M. Georgiev, M. (2017l). Motivation and stimulation of workers as a basic aspect of the organization. // Scientific journal «Economics and finance». GPG Publishing Group, Pretoria, South Africa, Challenges and opportunities of scientific thought development: Collection of scientific articles, 2017, pp. 44-53, ISBN 978-0-9942661-6-3.

Terziev, V., Banabakova, V., Ilsheva, M., Georgiev, M. (2017m). Controlling as a management function of the organization. // Scientific journal «Economics and finance». GPG Publishing Group, Pretoria, South Africa, Challenges and opportunities of scientific thought development: Collection of scientific articles, 2017, pp. 138-145, ISBN 978-0-9942661-6-3.

Terziev, V., Kanev, D. (2017n). Education and behavioural failures. // Proceedings of ADVED 2017- 3rd International Conference on Advances in Education and Social Sciences 9-11 October 2017- Istanbul, Turkey, 2017, ISBN: 978-605-82433-0-9, pp.733-742.

Terziev, V., Latyshev, O., Georgiev, M. (2017o). Building competencies for social work through continuing vocational training. // Proceedings of ADVED 2017- 3rd International Conference on Advances in Education and Social Sciences 9-11 October 2017- Istanbul, Turkey, 2017, ISBN: 978-605-82433-0-9, pp.754-772.

Terziev, Venelin. (2017p). Social entrepreneurship as an opportunity to model an active social program. // Proceedings of SOCIOINT 2017- 4th International Conference on Education, Social Sciences and Humanities 10-12 July 2017- Dubai, UAE, 2017, ISBN: 978-605-82433-1-6, pp.654-660.

Terziev, V., Nichev, N. (2017q). Strategic framework for social entrepreneurship development in Bulgaria. // Proceedings of SOCIOINT 2017- 4th International Conference on Education, Social Sciences and Humanities 10-12 July 2017- Dubai, UAE, 2017, ISBN: 978-605-82433-1-6, pp.531-540.

Terziev, V., Arabska, E. (2017r). Social entrepreneurship development in Bulgaria. // XIV International Scientific Conference Management for Engineering'17 ISSN 1310-3946, ISSN 1314-6327, Days of Science at the Technical University, 2017 june 25-28, 2017 Sozopol, Bulgaria, 2017, pp.495-503.

Terziev, V., Arabska, E. (2017s). Analysis of the process of social entrepreneurship in Bulgaria. // XIV International Scientific Conference Management for Engineering'17 ISSN 1310-3946, ISSN 13146327, Days of Science at the Technical University, 2017 june 25-28, 2017 Sozopol, Bulgaria, 2017, pp.486-494.

Terziev, Venelin. (2017t). Social entrepreneurship as an opportunity to model an active social program. // Topical issues of contemporary science: Collection of scientific articles. - C.E.I.M., Valencia, Venezuela, 2017, ISBN 978-0-9942661-1-8, pp.6-12.

Terziev, Venelin. (2017u). Social policy as theory and practice in Bulgaria. // Topical issues of contemporary science: Collection of scientific articles. - C.E.I.M., Valencia, Venezuela, 2017, ISBN 978-0-99426611-8, pp.13-18. 